\title{
Question Word in the Mandarin Language
}

\author{
Xu Yunyu \\ Indonesian language teacher at Asian \& African Studies Faculty, \\ Tianjian Foreign Studies University, China \\ candy-xuyunyu@hotmail.com
}

\begin{abstract}
In an interrogative sentence in Mandarin language, a question word can be placed in the beginning, middle or end of a sentence. Because of the different nation and culture, when a foreign student learns Mandarin, they find it difficult to understand the question words and the position of the question words in that language. Because of that, the writer proposes to explain such problems. This research aims to find out what are the types of question words in Mandarin, and also to explain the function and usage of question words in the Mandarin interrogative sentence. An interrogative sentence is a very important sentence.

In Mandarin, the following question words: 谁(shuí) “Who”, 在哪里(zài năli) “where”, 在哪儿(zài năer) “where”, 为什么(wèi shénme) “why”, 怎么(zěnme) “why”，多少（duō shăo） “how many”，多久(duō jiǔ) “how long”，什么时候 (shénme shíhòu) “when”，什么(shénme) “what”，做什么(zuò shénme) “why”，干 什么(gàn shénme) “why”, 干嘛(gànma) “why” and so on are used to ask "who”, "where", "what", "how much", "when", "what time", and "why". Those words have different functions and usage.

Each sentence has a certain structure and word order. A question word can be placed in the beginning, middle, or end of a sentence. When the place is changed, there is a possibility of miscommunication.
\end{abstract}

Keywords: interrogative sentence, Mandarin language.

\section{A. INTRODUCTION}

\section{Background of the Study}

In daily life, it is very common to greet, make casual jokes, and pose questions to each other. By communicating, we can know many things, expand our knowledge, and exchange ideas. Apart from that, communication can inspire new ideas.

In communication, there is always a question-and-answer interaction, in which each individual needs to pay attention to the question that he/she proposes. An interrogative sentence is one of the most important sentences in any language in the world, because only by asking questions the communicator can eliminate his/ her unawareness, doubts, and uncertainties about something that is completely unknown to them or that they know very little about. (Wijana, 1981:1)

It is the same in Mandarin language. In an interrogative sentence in Mandarin language, a question word can be placed in the beginning, middle or end of a sentence. Because of the different nation and culture, when a foreign student learn Mandarin, they find it difficult to understand the question words and the position of the question words in that language. Because of that, the writer proposes to explain such problems.

\section{Purpose of the Study}

This research aims to find out what are the types of question words in Mandarin, and also to explain the function and usage of question 
words in the Mandarin interrogative sentence.

\section{Benefits of the Study}

This research hopes to give contribution to the foreign language learner, especially those who are interested in linguistics. Moreover, this research is dedicated to the foreign language learner who wants to study Mandarin or wants to find out more about the Mandarin language (specifically about the question words in the Mandarin language).

\section{B. THEORETICAL FRAMEWORK}

\section{Question Word}

Question word is a mark of an interrogative sentence which changes the word or the words being asked. A few question words that are frequently used are "What", "How", "How much", "Where", "Why", and so on.

\section{Interrogative Sentence}

A sentence is a grammatical unit which are marked by an ending intonation. In written language, a sentence is marked by the sign (.), (?), (!), (;). (M. Ramlan, 2008). A sentence, based on its function, can be categorized into three types: affirmative sentence, interrogative sentence, and instructive sentence. Based on its name, an interrogative sentence functions to ask about something. (Ramlan, 1987:31,33).

An interrogative sentence is used to ask about something. An interrogative sentence begins with a question word and ends with a question mark.

Based on its functions, an interrogative sentence has several types: "Yes-No Questions", "Wh questions", and "Alternative questions".

\section{RESEARCH METHODS}

\section{Source of the Study}

The data for this research are obtained from books in the Gadjah Mada University Library, internet articles, and also from books of Mandarin lessons that can support this research.

\section{Procedures and Techniques of Data Gathering}

In writing this paper, the writer gathers the data, test them, and then choose the appropriate data to make sure that the obtained information can really be used for this paper.

\subsection{Data Analysis}

The data that are gathered are then analyzed. The analysis method and techniques that are used in this paper is an equalization method with the technique of choosing the determining factor (as described by Sudaryanto, 1985:212). Moreover, this research will also analyze the similarities and differences between an interrogative sentence in Mandarin and in a foreign language.

\section{ANALYSIS}

\section{Pitch in Mandarin}

Every word in Mandarin has four pitch:

1. First pitch:- (flat)

2. Second pitch: $\square$ (raised pitch)

3. Third pitch: (Raising and Falling Pitch)

4. Fourth pitch: ' (Falling pitch)

The function of those four pitch are to differentiate the meaning of the word. The same syllable when pronounced with different pitch will produce different meanings. For example:

\begin{tabular}{|c|c|c|c|c|}
\hline Nada & & Bunyi & Aksara & Arti \\
\hline First pitch & Flat & wā & 挖 & Dig \\
\hline Second pitch & Raising & wá & 娃 & Infant/baby \\
\hline Third pitch & $\begin{array}{l}\text { Raising and } \\
\text { Falling }\end{array}$ & wă & 瓦 & Roof tile \\
\hline Fourth pitch & Falling & wà & 袜 & Socks \\
\hline
\end{tabular}




\section{Question Word in Mandarin}

Question word is one of the marks in the interrogative sentence which function to replace the word or words that are being asked. In Mandarin, the question words are 谁(shuí) “Who", 在哪里(zài năli) “where”, 在哪儿(zài nă'er) "where", 为什么(wèi shénme) "why", 怎么(zěnme) “why”, 多少（duō shăo）"how many"，多久(duō jiǔ) "how long”，什么时 候(shénme shíhòu) “when”，什么(shénme) “what"，做什么(zuò shénme) "why"，干什 么 (gàn shénme) "why”, 干嘛(gànma) "why”, and so on. According to the different purposes of the question, the question words can be classified into several categories:

\section{a) “Who", “Which", "Who (plural)"}

To ask about God, Angel, and human, the following question words can be used: “谁” (shuí) “Who”, 哪位(nǎ wèi) “which”, 哪些人 (nǎ xiē rén) "Who (plural)". Misalnya:

\section{(1).他是谁?}

tā shì shuí?

Who is he/she?

\section{(2). 谁完成了作业?}

Shuí wán chéng le zuò yè?

Who has finished the assignment?

\section{(3). 昨天你和谁一起吃晚饭?}

Zuó tiān nǐ hé shuí yī qĭ chī wăn fàn? Who did you have dinner with?

Sentence (1) is used to ask about a stranger. The respondent may reply with the name, profession, title, or the position of that person. Besides that, the respondent may also say "I don't know" or "I don't really know".

In sentence (2) the question maker wans to know who are the people who has finished the assignment. The respondent will name the people who have finished it.

Sentence (3) is used to ask who did the respondent have dinner with.
(4). 哪位是那个病人的家属?

Nă wèi shì nà gè bìng rén de jiā shǔ?

Which are the patient's family?

(5). 您的论文指导老师是哪位?

Nín de lùn wén zhǐ dăo lăo shī shì nă wèi ?

Who is your thesis-counsellor?

(6). 在我们班上, 哪些人有计划明年出国旅 游?

Zài wǒ měn bān shāng, nă xiē rén yǒu jì huà míng nián chū guó lǜ yóu?

In our class, who are the people that plan to take a trip abroad next year?

\section{(7). 哪些人经常去唱卡拉ok?}

Nă xiē rén jīng cháng qù chàng kă lā okay? Who are the people that often go to karaoke?

In sentence (4) and (5), the word "nă wèi"'(who) is a singular question word that asks the name of a person. In sentence (6), (7), the word "nă xiē rén"(who) is a plural question word that asks the name of the people, in other words, "nă xiē rén" (who) is used to know the names of more than one person.

\section{b) "Where"}

The question word "where" is used to ask for a place. In Mandarin, the question word "where" is often followed by the preposition 在(zài) which means “at", 从(cóng) which means "from", 去(qù) which means "to".

在哪里(zài năli) or 在哪儿(zài nă'er) which means "where" is used to ask about a place, the word 从哪里(cóng năli)"or 从哪儿 (cóng nă'er) which means "from where" is used to ask about the origin or a place that a person leaves from, the word 去哪里(qù năli) or 去哪 儿(qù nă'er) which means "where to" is used to ask about a destination. For example:
(8). 你住在哪里?
或 你住在哪儿?
Ní zhù zài năli? or
Ní zhù zài 
nă'er?

Where do you live? = $\underline{\text { Where do }}$ you live?

(9).你从哪里来? 或 你从哪儿来? Nĩ cóng năli lái? or Nǐ cóng nă'er lái?

Where are you from? = You are from where?

(10). 苏西去哪里了? 或 苏西去哪 儿了?

Sū xī qù năli le ? $\quad$ or $\quad$ Sū xīqù nă'er le?

Where is Susi going? = Where is Susi going?

In sentence (8), the word 在哪里(zài năli) with 在哪儿(zài nă'er) are synonymous words to ask about the present place. In sentence (9), the word 从哪里(cóng năli) ”or 从哪儿(cóng nă'er) are synonymous words to ask about the origin or the place from which a person came. In sentence (10), the word 去哪里(qù năli) is used to ask about a place. While 去哪儿(qù nă' er) is used to ask about destination. They are both synonymous words.

\section{c) “What"}

The question word "What" is used to ask about an action. In Mandarin, there are several words that mean "what", those are: 做什么 (zuò shénme), 干什么(gàn shénme), 干嘛 (gànma). For example:

\section{(11). 那几个孩子正在做什么?}

Nà jǐ gè hái zi zhèng zài zuò shénme?

What are the kids doing?

(12). 你在王什么?

Nǐ zài gàn shénme?

What are you doing?

atau

You are doing what?
(13). 那个人将要王嘛?

Nà gè rén jiāng yào gànma?

What will that person do?

or

The person will do what?

The word 做什么(zuò shénme), 干什么 (gàn shénme), 干嘛(gànma) are synonymous words that mean "what". Because the phrases "doing what" dan "about to do what" can be shortened, therefore sentence (12) and (13) in Mandarin can each be translated into two kinds of sentences.

\section{d) "Why"}

The question word "why" is used to ask about a cause or reason. In Mandarin, the question words that mean "why" are 为什么 (wèi shénme), 怎么(zěnme). For example:

(14). 为什么这么热?

Wèi shén me zhè me rè?

Why is it so hot?

(15). 他怎么还没有来?

Tā zěnme hái méi yǒu lái?

Why hasn't she arrived?

The word 为什么(wèi shénme) and 怎 么(zěnme) are synonymous words for "why". Because both words are used to ask "why", sentence (14) and (15) in Mandarin can each be translated into two kinds of sentences.

\section{e) "When", "how long"}

The question word 什么时候 (shénme shíhòu) which means "when" is used to ask about the time. The word 多久(duō jiǔ) which means "how long" is used to ask about duration. For example:

(16). 你什么时候将要结婚?

Nǐ shénme shíhòu jiāng yào jiē hūn?

When will you get married? 
(17). 您多久回家乡一次?

Nǐn duō jiǔ huǐ jiā xiāng yī cì?

How long will you go back to your hometown?

\section{f) "How much"}

The question word "how much" is used to ask about sums and numbers. In Mandarin, the word that means "how much" are 多少 (duōshăo). For example:

\section{(18). 那本书多少钱?}

Nà běn shū duōshăo qián?

How much is that book?

(19). 你的手机号码是多少?

Nǐ de shǒu jī hào mă shì duōshăo?

What's your phone number?

\section{g) "What"}

The word 什么(shénme) which means "what" is used to ask about things, plants, and animals. For example:

(20). 那个漂亮的女孩在看什么书?

Nà gè piào liàng de nü hái zài kàn shénme shū?

What's the book that the beautiful lady reads?

\section{(21). 那是什么衣服?}

Nà shì shěnme yī fú?

What's that dress?

\section{E. CONCLUSION}

An interrogative sentence is a very important sentence. By asking questions, we can expand our mind. In Mandarin, the following question words: 谁(shuí) “Who", 在哪里(zài năli) “where”, 在哪儿(zài nă'er) “where”, 为 什么(wèi shénme) “why”, 怎么(zěnme) "why” , 多少（duō shăo） “how many”, 多久(duō jiǔ) “how long”, 什么时候(shénme shíhòu) “when”，什么(shénme) “what”，做什么(zuò shénme) “why”, 干什么(gàn shénme) "why” , 干嘛(gànma) "why" and so on are used to ask "who", "where", "what", "how much", "when", "what time", and "why". Those words have different functions and usage.

Each sentence has a certain structure and word order. A question word can be placed in the beginning, middle, or end of a sentence. When the place is changed, there is a possibility of miscommunication.

\section{REFERENCES:}

Leech, G., \& Jan Svartive.1985. A Comunication Grammar of English.

Alexander, L.G., \& Qixin, H. 2010. New Concept English (new edition). Beijing: Beijing Foreign Language Education Press.

Wijana, P. 2009. Berkenalan dengan Linguistik. Universitas Gadjah Mada.

Ramlan. 2001. Sintaksis. Universitas Gadjah Mada.

Chalker, S., \& Weiner, E. 1998. Oxford Dictionary of Modern English Grammar. Oxford University Press.

Sudaryanto. 1987. Deskripsi Bahasa. Universitas Gadjah Mada.

Chengwei, Z. 2003. College English Using English Grammar. Shanghai: Shanghai Foreign Language Education Press.

沈丽壁, 2001, 中文语法疑问词移动之研 究分析

吕淑湘，1989年，语语法分析问题,商务印书 馆

郡敬敏, 1996年, 现代汉语疑问句研究, 华东师大出版社

Website:http://baike.baidu.com/view/935953. Website: http://baike.baidu.com/view/1373088. Website: http://baike.baidu.com/view/1656124. 